\title{
THE CLASSIFICATION FACTORS OF PARTICIPATING STATES IN THE IMPLEMENTATION OF ENVIRONMENTAL PROJECTS
}

\author{
Ukrainian State University of Chemical Technology, Dnipro, Ukraine
}

\begin{abstract}
The article substantiates the development of interaction of the industrial enterprises with State institutions and predicted the expected results of such cooperation. According to the results of marketing research revealed main trends of financing State environmental developments. Investigated the main forms and methods of stimulating such cooperation taking into account the international experience. The article noted that the successful combination of potential industrial enterprise and the State is the key to the transition to ecological-oriented development. This in turn strengthens competitiveness of industrial enterprises on both the domestic and foreign markets. Industrial enterprises in a number of regions are the main sources of jobs, and even those that make up the city. But, their environmental potential has been exhausted due to the use of obsolete techniques and technologies. Therefore, the intervention of the State in the promotion of production is one of the tools to overcome/prevention of environmental problems that may arise in the process of industrial enterprise. Therefore, the analysis of this issue is particularly relevant. Environmental problems faced by the company can be funded by the State. When the environmental disaster of the State scale it can be $100 \%$ financing; industrial enterprises, which are potentially environmentally hazardous at the State level can be financed partially; industrial enterprises are on the ecology-oriented development will be able to get an interest-free loan from the State. It is necessary to take into account the global trend towards environmentally sound production.
\end{abstract}

Keywords: ecologization, marketing research, financial efficiency, state financing, industrial enterprises.

DOI: $10.32434 / 2415-3974-2018-8-2-50-55$

\section{Introduction and setting challenges}

World practice prevention and overcoming environmental problems at the industrial enterprises has many examples of how direct and indirect government intervention in these processes. This can be the creation, implementation and control of programs that contain technological projects and financial means to support them; financing local scientists; the provision of soft loans to industrial enterprises for the purchase and implementation of ecological innovation; fractional part in the project - it can be provided as financial resources and providing the latest developments of science and technology, new equipment, etc.; full financing of ecological project in the transition of industrial enterprises on ecological-oriented development.

The main problem of environmentally sound production is lack of awareness of top management with regard to: the possible consequences in case of environmental issues, alternative variants of its warnings (force of the enterprise, attracting domestic and/or foreign scientists), economic opportunity/ desire to resource allocation, getting the social and economic effect of the introduction of new environmental initiatives on their enterprise.

In this regard, the question of State control over the process of the transition of domestic industrial enterprises to the ecology-oriented development. In particular, it is the control of strategic and tactical plans of the enterprise, its main economic indicators (profitability, ROI, etc.), marketing (markets, market share, introducing new products into production etc), social (payment of labour, labour protection, working conditions, environmental protection, ensuring personnel stay, etc.) in dynamics.

\section{Analysis of research and publications}

A significant contribution to the study of the State's participation in the implementation of various projects, in particular ecological, made such leading 
scientists as: A. Averchenko, V. Anishchenko, O. Balackij, I. Vasina, I. Dragan, O. Dmytruk, S. Doroguncov, Z. Gerasymchuk, V. Gorlachuk, M. Holubec, K. Kartashova, M. Kovalenko, V. Kucheryviy, O. Lapko, T. Macmevich, R. Fokov, O. Shaporenko, A. Shevchuk. However, despite the significant achievements of scientists in relation to the environmental component of the work of enterprises, many questions research of influence of the State on this issue remain out of focus.

The purpose of the article is the development of the classification factors of participating States in the implementation of environmental projects.

\section{Summary of the basic material}

In terms of internationalization and globalization of world markets, the ecological component of the work of enterprises, becoming one of the most important in determining its competitiveness. It concerns not only the final product, but also to the characteristics of its production, the safety of working conditions and safety for surrounding areas. All these factors led to the intervention of the State in controlling the environmental component of the activities of the industry.

Ensure environmental-oriented development of modern enterprises industry promotes the internationalization and globalization of economic processes in Ukraine. These measures should lead to stabilization of the economic situation in the country and provide an opportunity to develop industrial enterprises according to the requirements of the modern world economic space. Introduction of environmental development, in most cases, it is not possible without the interference of the State. However, you should note that the instruments of intervention may be different.

The core of the main causes of such State acts directly, the economic situation in the country, where it is industrial enterprise, and in the world. Given the volume of investment resources, which are essential to the enterprise for ecological modernization, the solution of this problem should not only be controlled by the State, but also have State support. Support State can occur through both financial and other resources, which lacks an industrial enterprise.

Increasing the environmental activity of industrial enterprises requires large-scale legal, economic, social, and other mechanisms that will work with the participation of State intervention. State intervention can be of different shapes, the main of which are: observation, participation or control.

At present, there is no unified approach, which would be conducted effectively (both economic and social) evaluation of the interference of the State in solving various environmental quality at the industrial enterprises. It is necessary to highlight the main aspects of the analysis of this intervention, which depend on the degree of environmental safety, and it is the environmental disaster of the State scale; industrial enterprises, which are potentially environmentally hazardous at the State level; industrial enterprises that want to introduce ecofriendly inventions and developments.

We have conducted market research with regard to the participation of States in the implementation of environmental engineering [1]. The study involved two groups of respondents (clusters). The first clusterscientists environmentalists, the second clusterrepresentatives of industrial enterprises of Ukraine. The results of the research there were remarkable relative frequency that is evaluated only after conducting a study, based on actual data. Relative frequency shows that the fate of the experiment result of the onset of a given result $\mathrm{W}(\mathrm{A})$. The relative frequency of an event and is called the ratio $\mathrm{M}(\mathrm{A})$ of the total number $n$ is actually performed tests, i.e.

$\mathrm{W}(\mathrm{A})=\frac{\mu(\mathrm{A})}{\mathrm{n}}$

Since $0 \leq \mathrm{m}(\mathrm{A}) \leq \mathrm{n}$, then the relative frequency is the number of 0 to 1 [2].

The results of calculations of relative frequencies for the results of the studies of the responses of both clusters are listed in the table.

More clearly, we can see in Fig. 1.

The next stage of our study is to compare the answers of the respondents both clusters, namely scientists-ecologists and representatives of industrial enterprises. Comparison of responses we can make using the correlation coefficient (r) by the formula.

We calculate these indicators of the correlation coefficient by the formula (2)

$$
r_{n}=\frac{\sum_{i=1}^{n}\left(x_{i}-\bar{x}\right)\left(y_{i}-\bar{y}\right)}{\sum_{i=1}^{n}\left(x_{i}-\bar{x}\right)^{2} \sqrt{\sum_{i=1}^{n}\left(y_{i}-\bar{y}\right)^{2}}}
$$

The relative frequencies with respect to the answers to questions about government involvement in the implementation of environmental projects

\begin{tabular}{c|c|c|c|c}
\hline $\begin{array}{c}\text { Variants of } \\
\text { answers }\end{array}$ & $\begin{array}{c}\text { The provision of interest-free loan for the purchase } \\
\text { of developments in the field of ecology }\end{array}$ & $\begin{array}{c}\text { Partial participation } \\
\text { in buying }\end{array}$ & $\begin{array}{c}100 \% \text { payment } \\
\text { of State }\end{array}$ & $\begin{array}{c}\text { Your } \\
\text { version }\end{array}$ \\
\hline Cluster 1 & 0,31 & 0,22 & 0,39 & 0,08 \\
\hline Cluster 2 & 0,46 & 0,41 & 0,08 & 0,05 \\
\hline
\end{tabular}




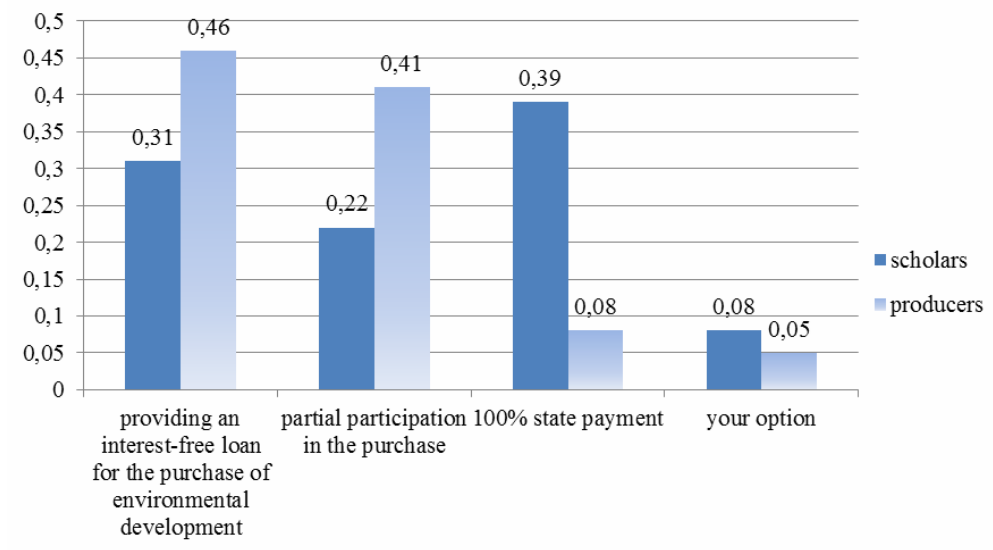

Fig. 1. The results of the responses to the question concerning the participation of the State in environmental development (relative frequencies).

where: $x_{i}, y_{i}-$ is a set of random variables; $i=1,2, \ldots, n$; $r_{n}$ - the correlation coefficient.

The results of the calculations of the $r_{n}=-0.79$, which indicates that the point of view of participation of States in the implementation of environmental projects between scientists who sell their eco-friendly development, and representatives of the industrial enterprises are diametrically different.

Analyzing the responses of two groups of respondents: scientists-ecologists and representatives of industrial enterprises, we tend to more attention paid to the answers which were given by representatives of industrial enterprises, precisely because of the fact that the enterprise has not only bought scientists, environmental development, but also capable of their funding under the conditions of different support their Government in this matter (fig. 2).

For the calculation of the efficiency of the State funding of environmental development, it is necessary to discover which result are expecting to get all interested persons, that is, the State industrial enterprise and society (or nature, as ecological
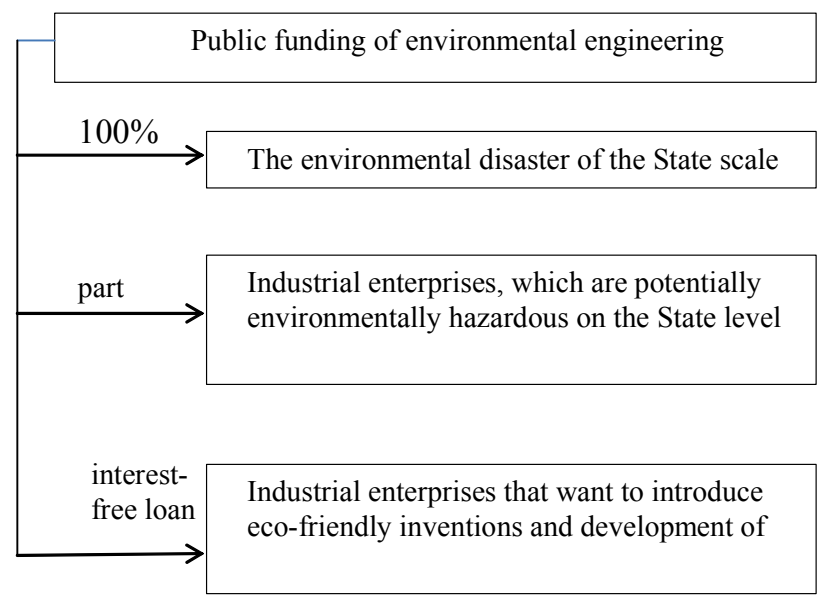

Fig. 2. The level of public funding of environmental engineering for industrial enterprises
Wednesday of human). Basic level we can consider the efficiency at the State level. But it is necessary to note, that the State is the guarantor of the rights and obligations of the people, especially with environmental safety. The main task at this level is not so much economic, as much as the social effect. The main indicator at this level is the satisfaction and environmental safety for the environment. We noted that the State can absolutely finance ecological event only under the condition of environmental catastrophe on the scale of the State, and the effectiveness of such public funding will be in the preservation of life and health of its citizens and security the ambient environment.

The next step is the analysis of industrial enterprises, which are potentially environmentally hazardous at the State level. Funding environmental development State must take place within the framework of the partial participation of both sides in implementing the environmental data. The size of the share of the State should be determined after an independent monitoring (audit) the financial position of the industrial enterprise and determination of its solvency for the procurement and implementation of this development. The funds, which are not to be missed (according to independent auditors) must cover the State. The percentage of participation of the State in funding environmental development is a kind of indicator of a country's economy as a whole. The better the economic situation of the enterprise, the less of the will to invest State and most of the costs will be just the company that shows its financial solvency and reliability. That is, when its market share stable country in participating in such projects can come down to a minimum (depending on the extent of the potential environmental threat).

One of the more cost effective for the State is to provide interest-free loans to businesses that are ready to implement eco-friendly inventions and developments at its facility. This will not only solve 
the environmental problems, but also to return the funds to the State budget-their use in various sectors of the economy of the country.

From a practical point of view, the maximum efficiency of the State financing of ecological engineering is possible under the terms of a comprehensive approach to all their components (one hundred percent funding, partial funding, the provision of interest-free loan). In this capacity it is necessary to take into account both economic and social effect of such investment projects.

In practice, provide an effective assessment of the State of implementation of environmental developments at industrial enterprises is only possible by applying a comprehensive approach. It involves the coordination of all indicators at different levels, which have not only quantitative, but also qualitative characteristics.

Ensure environmental-oriented development of modern enterprises industry promotes the internationalization and globalization of economic processes in Ukraine. These measures should lead to stabilization of the economic situation in the country and provide an opportunity to develop industrial enterprises according to the requirements of the modern world economic space. Introduction of environmental development, in most cases, it is not possible without the interference of the State. However, you should note that the instruments of intervention may be different.

When choosing an industrial enterprise for financing environmental developments with public funds requires a general comparative - analytical indicators of efficiency investments and innovations in a particular environmental project. Main indicators have to be [3], [4]:

1. The planned volume, unit.

2. The volume of realization of the break-even point:

$$
\mathrm{B}_{\text {кр }}=\frac{\Pi В}{Ц-3 B_{\text {од }}},
$$

where: $\mathrm{B}_{\mathrm{kp}}-$ volume of realization of the breakeven point; ПВ - fixed costs; Ц - the unit price of products; $3 \mathrm{~B}_{\text {од }}$ - variable costs per unit of production. 3. Area security:

$$
\text { ЗБ }=\mathrm{V}-\mathrm{B}_{\text {кр }},
$$

where: ЗБ - area security; $\mathrm{V}-$ the amount of the proceeds; $B_{к р}-$ volume of realization of the breakeven point.

4. The area security in percentage to the amount that is planned, $\%$

5. Net income
$Д_{4}=\Pi_{ч}+\mathrm{A}$

where: $\Pi_{ч}-$ net profit in the first year of implementation of investment project under uniform flow of income throughout the period of recoupment of investments, UAH.; A - depreciation charges for the full recovery of the fixed assets in the calculation for the year of implementation of investment project under uniform flow of income for the entire payback period, UAH.

6. Net profit UAH:

$\Pi_{4}=\Pi *(1-H)$

where: $\Pi-$ net profit in the first year of implementation of investment project under uniform flow of income, UAH.; $\mathrm{H}$ - the standard income tax in fractions of units.

7. The need for investment resources, UAH.

8. Net Present Value- NPV:

$N P V=\sum_{t=1}^{n} \frac{B_{t}-C_{t}}{(1+r)^{t}}$

where: for year $t: B_{t}$ - revenues from sales of products that will be produced as a result of the implementation of the investment; $\mathrm{C}_{t}-$ the costs of the project; $\mathrm{r}-$ the discount rate; $\mathrm{B}_{\mathrm{t}}=$ the volume of basic types of marketable products, which will be produced as a result of the implementation of the investment, multiplied by the price per unit of production (according to type) $\mathrm{C}_{\mathrm{t}}=$ the volume of basic types of marketable products, which will be produced as a result of investment, multiplied by the costs at issue one unit of product.

9. Profitability of investments designed to create, manufacture and use of innovations per year is defined by the formula, $\%$ :

$$
\mathrm{P}_{\mathrm{i}_{1}}=\frac{Д_{\mathrm{i}_{1}}}{\mathrm{~K}_{\mathrm{i}_{1}}} \cdot 100=\frac{Д_{\Pi_{1}}+Д_{\mathrm{c}_{1}}+Д_{\mathrm{B}_{1}}}{\mathrm{~K}_{\Pi_{1}}+\mathrm{K}_{\mathrm{c}_{1}}+\mathrm{K}_{\mathrm{B}_{1}}} \cdot 100 \%,
$$

where: $\mathrm{P}_{\mathrm{i}_{1}}-$ the profitability of investments designed to create, manufacture and use of innovations, $\%$; $Д_{i_{1}}$ - the total amount of income; $Д_{\Pi_{1}}-$ the amount of income received by the production of ecological innovations per year, UAH.; $Д_{c_{1}}-$ the amount of income received by creating ecological innovations per year, UAH.; $Д_{B_{1}}-$ the amount of the income is obtained through the use of environmental innovations per year, UAH.; $\mathrm{K}_{\mathrm{i}}-$ the total amount of capital investments designed to create, manufacture and use of innovations, UAH; $\mathrm{K}_{\mathrm{\Pi}_{1}}, \mathrm{~K}_{\mathrm{c}_{1}}, \mathrm{~K}_{\mathrm{B}_{1}}$ - capital investments aimed at the creation, the production and use of innovations, $\mathrm{UAH}$. 
10. The internal rate of return, $\%$

$$
\sum_{\mathrm{t}=0}^{\mathrm{T}} \frac{\mathrm{K}}{\left(1+\mathrm{E}_{\mathrm{BH}}\right)^{\mathrm{t}-\mathrm{t}_{\mathrm{r}}}}=\sum_{\mathrm{t}=0}^{\mathrm{T}} \frac{\text { Д }}{\left(1+\mathrm{E}_{\mathrm{BH}}\right)^{\mathrm{t}-\mathrm{t}_{\mathrm{r}}}},
$$

where: $\mathrm{K}$ - initial costs UAH.; $\mathrm{T}$ - last year, the use of the investment project; Д - income, UAH.; $\mathrm{E}_{\text {вн }}$ - internal rate of return; $\mathrm{t}-$ year of investment; $\mathrm{t}_{\mathrm{r}}$ - the estimated year in which are costs (current and one-off costs) and income.

$$
I R R=E_{H}+\frac{\left(E_{P}-E_{H}\right) N P V_{H}}{N P V_{H}-N P V_{P}} \cdot 100 \%,
$$

where: $E_{H}=0,12$ - normative rate discounting; $E_{P}-$ the estimated discount rate; $\mathrm{NVP}_{\mathrm{H}}-$ regulatory net present value; $\mathrm{NVP}_{\mathrm{P}}-$ the estimated net present value.

11. Payback period of investment project

- the uniform receipt of income during the period of recoupment of investments:

$$
\mathrm{T}=\frac{\mathrm{K}}{\Pi_{ч}+\mathrm{A}} \leq \mathrm{T}_{\text {ео }} \text { або } \mathrm{T}=\frac{\mathrm{K}}{Д_{ч}} \leq \mathrm{T}_{\text {ео }},
$$

where: $\mathrm{T}-$ investment project payback period, years; $\Pi_{ч}-$ net profit in the first year of implementation of investment project under uniform flow of income throughout the period of recoupment of investments, UAH.; $\mathrm{K}$ - the full amount of the costs for the implementation of the investment project, include the costs of research and development work, UAH.; $\Pi_{\mathrm{i}}-$ net profit in the i-year, UAH.; $\mathrm{T}_{\text {eо }}-$ economically justified payback period of investment is determined by the direction of industrial enterprise or the investor (country), year; A - depreciation charges for the full recovery of the fixed assets in the calculation for the year of implementation of investment project under uniform flow of income for the entire payback period, UAH.; $A_{i}-$ depreciation charges on a full recovery in the i-year, UAH.; $Д_{4}-$ net income in the first year of implementation of investment project under uniform flow of income throughout the period of recoupment of investments, UAH.

- income is unequally distributed across the years of implementation of the investment project for the entire period of its recoupment:

$$
-\mathrm{K}+\sum_{\mathrm{i}=1}^{\mathrm{T}}\left(\Pi_{\mathrm{i}}+\mathrm{A}_{\mathrm{i}}\right) \geq 0 \text { при цьому } \mathrm{T} \leq \mathrm{T}_{\mathrm{eo}} \text {, }
$$

12. Discount payback period, years:
$\mathrm{T}_{\text {ок (диск) }}=\frac{\sum_{\mathrm{t}=1}^{\mathrm{n}} \mathrm{B}_{\mathrm{t}}}{\sum_{\mathrm{t}=1}^{\mathrm{n}} \mathrm{C}_{\mathrm{t}}\left(1+\mathrm{E}_{\mathrm{P}}\right)^{\mathrm{t}}}$,

where: $B_{t}-$ investment in the project in the period $\mathrm{t} ; \mathrm{C}_{\mathrm{t}}-$ revenue in the period $\mathrm{t} ; \mathrm{E}_{\mathrm{P}}-$ adopted in the project rate discounting.

World practice prevention and overcoming environmental problems at the industrial enterprises has many examples of how direct and indirect government intervention in these processes. This can be the creation, implementation and control of programs that contain technological projects and financial means to support them; financing local scientists; the provision of soft loans to industrial enterprises for the purchase and implementation of ecological innovation; fractional part in the project - it can be provided as financial resources and providing the latest developments of science and technology, new equipment, etc.; full financing of ecological project in the transition of industrial enterprises on ecological-oriented development.

However, despite the existence in Ukraine of powerful scientific schools (and on greening production including), the existence of experience in creation of ecological scientific product, unfortunately, the interaction between industrial enterprises and national research schools, to date, almost lost. The main reasons for this is the lack of favourable conditions for effective work of the industrial enterprise - domestic scholars ", which led to the dissolution of their mutually beneficial partnership. However, establishing these relationships is one of the strategic tasks of the State, not only with regard to the environmental dimension of this issue.

Increasing the environmental activity of industrial enterprises requires large-scale legal, economic, social, and other mechanisms that will not work without government intervention. State intervention can be of different shapes, the main of which are: observation, participation or control.

In practice, provide an effective assessment of the State of implementation of environmental developments at industrial enterprises is only possible by applying a comprehensive approach. It involves the coordination of all indicators at different levels, which have not only quantitative, but also qualitative characteristics.

\section{Conclusions}

In this regard, the question of State control over the process of the transition of domestic industrial enterprises to the ecology-oriented development. In particular, it is the control of strategic and tactical plans of the enterprise, its main 
economic indicators (profitability, ROI, etc.), marketing (markets, market share, introducing new products into production etc), social (payment of labour, labour protection, working conditions, environmental protection, ensuring personnel stay, etc.) in dynamics.

\section{REFERENCES}

1. Chupryna, N.M. (2018) Upravlinnia ekolohooriientovanym rozvytkom promyslovykh pidpryiemstv [Management of ecologically-oriented development of industrial enterprises]. Dnipro: DVNZ UDKhTU [in Ukrainian].

2. Otnosytel'naia chastota sluchajnoho sobytyia [Relative frequency of a random event]. (n.d.) Retrieved from http:// festival.1september.ru/articles/527524/ [in Russian].

3. Krylov, E.Y., Vlasova, V.M., Zhuravkova, Y.V. (2003). Analyz effektyvnosty ynvestytsyonnoj y ynnovatsyonnoj deiatel'nosty predpryiatyia [Analysis of the effectiveness of investment and innovation activities of the enterprise] ( $2^{\text {nd }}$ ed., rev.). M.: Fynansy y statystyka [in Russian].

4. Vakhrushyna, M.A. (2005). Upravlencheskyj analyz [Management analysis] (2 $2^{\text {nd }}$ ed., rev.). M.: Omeha-L [in Russian].

Received 20.10.2018

Reviewer: ass. prof., prof. Kolesnikov V.P.

\section{КЛАСИФІКАЦІЯ ФАКТОРІВ УЧАСТІ ДЕРЖАВ У РЕАЛІЗАЦІЇ ЕКОЛОГІЧНИХ ПРОЕКТІВ}

\section{Чуприна Н.М., Ковальова М.О.}

У статті обтрунтовано розвиток взаємодії промислових підприємств з державними установами та спрогнозовані очікувані результати такої співпраці. За результатами здійснених маркетингових досліджень виявлені основні тенденції можливості фінансування державою екологічних розробок. Досліджено основні форми та методи стимулювання такої співпраці з урахуванням міжннародного досвіду. У статті зазначено, що вдале поєднання потенціалу промислового підприємства та держави є запорукою переходу до еколого-орієнтованого розвитку. Це в свою чергу укріпить конкурентні позииії промислових підприємств як на вітчизняному, так і на зовнішніх ринках збуту. Промислові підприємства в ряді регіонів України $\epsilon$ основними джерелами робочих місиь, $i$, навіть місто утворюючими. Але, їх екологічний потенціал вичерпано, через застосування застарілих технік та технологій. Саме тому, втручання держави в екологізацію виробництва є одним з інструментів подолання/попередження екологічних проблем, які можуть виникнути в процесі роботи промислового підприємства. Саме тому аналіз цієї проблеми є особливо актуальним. Екологічні проблеми, з якими стикається підприємство можуть бути профінансовано державою. При екологічній катастрофі держсавного маситабу це може бути $100 \%$ рінансування; промислові підприємства, які є потенційно екологічно небезпечними на держсавному рівні можуть фінансуватися частково; промислові підприємства, які переходять на еколого-орієнтований розвиток матимуть можсливість отримати безвідсотковий кредит від держави. При иьому необхідно враховувати глобальні тенденції до екологізації виробництва.

Ключові слова: екологізація, маркетингові дослідження, фінансова ефективність, державне фінансування, промислові підприємства.

\section{КЛАССИФИКАЦИЯ ФАКТОРОВ УЧАСТИЯ ГОСУДАРСТВ В РЕАЛИЗАЦИИ ЭКОЛОГИЧЕСКИХ ПРОЕКТОВ}

\section{Чуприна Н.Н., Ковалева М.А.}

В статье обоснована развитие взаимодействия промышленных предприятий с государственными учреждениями и спрогнозированы ожидаемые результаты такого сотрудничества. По результатам проведенных маркетинговых исследований выявлены основные тенденции возможности финансирования государством экологических разработок. Исследованы основные формы и методы стимулирования такого сотрудничества с учетом международного опыта. В статье указано, что удачное сочетание потенциала промышленного предприятия и государства является залогом перехода к эколого-ориентированному развитию. Это в свою очередь укрепит конкурентные позиции промышленных предприятий как на отечественном, так и на внешних рынках сбыта. Промышленные предприятия в ряде регионов Украины являются основными источниками рабочих мест, и даже градообразующими. Но, их экологический потенциал исчерпан, из-за применения устаревших техник и технологий. Именно поэтому, вмешательство государства в экологизацию производства является одним из инструментов преодоления / предупреждения экологических проблем, которые могут возникнуть в процессе работы промышленного предприятия. Именно поэтому анализ этой проблемы является особенно актуальным. Экологические проблемы, с которыми сталкивается предприятие могут быть профинансированы государством. При экологической катастрофе государственного масштаба это может быть $100 \%$ финансирования; промышленные предприятия, которые являются потенциально экологически опасными на государственном уровне могут финансироваться частично; промышленные предприятия, которые переходят на эколого-ориентированное развитие смогут получить беспроцентный кредит от государства. При этом необходимо учитывать глобальные тенденции к экологизации производства.

Ключевые слова: экологизация, маркетинговые исследования, финансовая эффективность, государственное финансирование, промышленные предприятия. 